\title{
THE NATURE OF LEUKEMIC BLOOD CELLS AS DETERMINED BY THEIR METABOLISM
}

\author{
BY WALTER KEMPNER \\ (From the Department of Medicine, Duke University School of Medicine, Durham)
}

(Received for publication December 5, 1938)

"The nature and etiology of leukemia are unknown" (1). Some authors $(2,3,4,5,6,7,8)$ are in favor of classifying the leukemias as malignant neoplasms of the blood-forming organs, because of the formation of leukocytes in unaccustomed organs, the new growth of leukemic tissue, and the flooding of the blood stream with abnormal primitive cells. Others (9) prefer to consider leukemia as a type of benign tumor formation, or tissue metaplasia, or simply as an excessive, unregulated production and outpouring of essentially normal young tissue cells. To solve the problem by means of morphological histology has proved impossible (10).

A new approach to this question was opened, however, by the methods of cellular physiology, and this paper presents experimental results obtained by these methods, which, it seems to me, give an unambiguous and definite answer to the question of the nature of leukemic cells.

As Warburg (11) has found, cells of benign, and to an even greater degree of malignant tumors, differ fundamentally from normal cells in their energy supplying metabolic reactions. In all normal undamaged animal cells the magnitude of the oxidative metabolism is considerably greater than the magnitude of the glycolytic metabolism and, under aerobic conditions, no splitting of sugar into lactic acid (glycolysis) occurs. In the metabolism of benign tumor cells and even more of cancer cells, the respiration-glycolysis ratio is disturbed; the rate of glycolysis is high as compared to the rate of respiration and a great amount of lactic acid is formed under aerobic conditions. This aerobic glycolysis, however, may have a different origin; it can be produced, for example, by poisoning the cells with cyanide, carbon monoxide, or arsenious acid, by various injuries leading to the gradual death of the cell, or, in the more sensitive organs, simply by keeping the tissue in Ringer's solution instead of its own plasma. Aerobic glycolysis as such, then, is not specific for malignancy, but rather the fact that the cancer cell can live and grow by its persisting glycolytic metabolism under aerobic and anaerobic conditions, whereas aerobic glycolysis in injured cells is only a metabolic phase of their dying off. If, therefore, under physiological experimental conditions, the determination of the cell metabolism reveals aerobic glycolysis of zero, it is certain that the tissue examined is normal and not cancer tissue, whereas the positive finding of aerobic glycolysis need not be specific for cancer cells, but may characterize either cancer metabolism or the dying off of any tissue within or without the body.

Since the results of experiments on the metabolism of white blood cells are scattered through the literature and there is no critical survey on the suitability or inadequateness of the methods employed, it seems advisable to give a bibliographical review on this subject.

Grafe (12) examined the blood of leukemic patients and showed that white blood cells have a high oxidative metabolism.

Levene and Meyer (13) were the first to show that leukocytes have a high glycolytic activity. This was confirmed by Bürger (14) for leukemic leukocytes.

Bakker (15) examined exudate leukocytes of rabbits, comparing their oxygen consumption and their glycolysis, and found a small rate of respiration together with high aerobic glycolysis. He concluded from these findings that white blood cells have cancer metabolism.

Fleischmann and Kubowitz (16) measured the metabolism of leukocytes from the blood of geese and from exudate of rabbits and found, like Bakker, in both instances high aerobic glycolysis. But since the aerobic glycolysis was higher in the white cells from exudate than in those from blood, they concluded that aerobic glycolysis in leukocytes is not a proof of cancer metabolism, but only a symptom of injury, as leukocytes will die off more rapidly in exudates than within the blood vessels.

Fujita (17) examined white blood cells and bone marrow of rats, Barron and Harrop (18) leukocytes from peritoneal exudates of rabbits, Jackson, Parker, and Glover (19) monocytes of rabbit's lung, Loebel, Shorr, and Richardson (23) monocytes of rabbit's peritoneum.

Common to all these experiments with mature animal leukocytes of various types, was the ambiguous result that the fermentative metabolism was high in comparison to the oxidative metabolism and that splitting of sugar into lactic acid took place under aerobic conditions. The original question remained unsolved, whether this me- 
tabolism of leukocytes which all investigators agreed was different from the metabolism of normal cells, actually represented cancer metabolism or was only due to injury or death of sensitive cells.

Regarding the metabolism of human leukocytes, Kempner and Peschel (22) examined mononuclear and polynuclear cells obtained from sterile blisters of the skin. They found the absolute metabolism figures considerably higher than those reported for the various animal leukocytes, but the type of metabolism as such was identical with that of the exudate leukocytes of animals : high glycolysis, relatively low respiration, and also lactic acid formation under aerobic conditions.

Barron and Harrop (18) studied oxygen consumption and glycolysis in blood of patients with chronic leukemia and found aerobic glycolysis present both in the blood of patients with lymphatic and with myeloid leukemia. Unfortunately, the oxygen consumption was measured in the total absence of carbon dioxide (alkaline in the side bulb) and at a $\mathrm{pH}$ probably above $8(\mathrm{pH}$ determinations are not given); glycolysis was examined in $\mathrm{N}_{2}$ instead of 5 per cent $\mathrm{CO}_{2} / 95$ per cent $\mathrm{N}_{2}$. Furthermore, in the experiments with leukemic blood cells there are no figures given which indicate the amount of lactic acid formed by the cells but only the amount of sugar consumed, so that it is not possible to decide how much of the sugar consumed under aerobic conditions was used in respiration, how much for the formation of glycogen (30), and how much was actually split into lactic acid. On the basis of these sugar determinations the authors state that polynuclear leukocytes possess a higher aerobic and anaerobic glycolysis than mononuclear leukocytes and calculating Warburg's so-called "excess of fermentation" $\left(\mathrm{U}=\mathrm{Q}_{\mathrm{M}}^{\mathrm{N}_{2}}-2 \mathrm{QO}_{2}\right)$ they conclude that the metabolism type of lymphatic leukemic blood cells resembles that of normal cells, whereas myeloid leukemic leukocytes show the metabolism type of cancer tissue. They further state that there is no difference in the metabolism of mature and immature granulocytes and of granulocytes from cases of leukocytosis or of myelogenous leukemia. Since the metabolism figures given in their paper are calculated per million cells, not per weight, it is difficult to compare them with the results of other investigators. For the sake of completeness, however, we have included them in Table I, assuming-very inaccurately-that the dry weight of 10 million white blood cells is equal to $1 \mathrm{mgm}$.

Glover, Daland, and Schmitz (20) made an extensive study of the metabolism of normal and leukemic leukocytes, determining the oxygen and sugar consumption in the blood of patients with lymphatic and myelogenous leukemia. They too, like Barron and Harrop (18), measured the oxygen consumption in the presence of alkaline, eliminating the physiological carbon dioxide content, and not at a physiological pH, but between 7.6 and 8.2. For the determination of glycolysis they did not use any lactic acid determinations but only sugar determinations, so that in this paper also it cannot be gathered how much of the sugar consumption is due to sugar oxidation, to the formation of glycogen from sugar, or to the splitting of sugar into lactic acid. Oxygen and sugat consumption were not determined in the same medium, the rate of glycolysis was calculated by deducting from the total sugar consumption the amount of sugar oxidized, assuming that all the oxygen consumed was used for the oxidation of sugar. In four cases of acute leukemia with for the most part very primitive cells (the authors say it has been impossible to determine exactly whether they were of lymphatic or myelogenous origin) they found the aerobic glycolysis higher than in cases of lymphatic and myelogenous leukemia with more mature cells, when using air to saturate the cell suspensions with oxygen. This, they state, was directly opposed to the results they obtained when the cell suspensions were exposed to 95 per cent oxygen. These conflicting results, however, are not due, as the authors think, to the difference between the effect of oxygen and that of air upon the cells. They only reveal the two other sources of error in the experiments under discussion. For, firstly, in the experiments in which the blood was saturated with air, the oxygen saturation (21 per cent) was evidently not sufficient to prevent the occurrence of completely anaerobic areasespecially since the blood was only submitted to "gentle agitation"-so that what was measured was not really the aerobic sugar consumption, but aerobic and anaerobic sugar consumption in undefined proportion; secondly, to the air used for saturation, no carbon dioxide was added, so that the experiment was done in the absence of carbon dioxide at an alkaline $\mathrm{pH}$, whereas to the 95 per cent oxygen 5 per cent carbon dioxide was added, thus producing physiological conditions as to carbon dioxide concentration and $\mathrm{pH}$. Determining the aerobic sugar consumption of the blood cells from five patients with myelogenous and five patients with lymphatic leukemia in this physiological milieu of 5 per cent $\mathrm{CO}_{2} / 95$ per cent $\mathrm{O}_{2}$, Glover and his coworkers actually did find aerobic glycolysis still present in all of the five cases of myelogenous leukemia, but it decreased with the immaturity of the cells. Of the five cases of lymphatic leukemia, they found aerobic glycolysis present in three cases and absent in two, independent of the maturity or immaturity of the cells. Unfortunately, in this series of experiments, the only ones without fundamental errors in technique, only the sugar consumption and not the oxygen consumption was determined.

Schlossmann (21) and Peschel (1) examined blood cells from patients with lymphatic leukemia, determining oxygen consumption, aerobic and anaerobic lactic acid formation under physiological conditions manometrically with the Warburg technique. They were the first who were able to show that these immature lymphocytes-provided they are preserved from all injury and examined under physiological conditions-possess a purely oxidative metabolism and no aerobic glycolysis at all. From these findings Peschel concluded: Since mature and immature lymphocytes have a very different metabolism, in that the immature leukemic lymphocytes have a purely oxidative metabolism and do not show any formation of lactic acid under aerobic conditions, it is in the first place definitely proved that leukemic lymphocytes in regard 
TABLE I

Summary of quantitative data on the metabolism of white blood cells (calculated for $1 \mathrm{mgm}$. of dry weight of cells per hour)

\begin{tabular}{|c|c|c|c|c|c|c|c|}
\hline Authors & \multicolumn{2}{|c|}{ Type of leukocytes } & 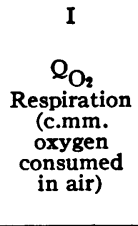 & $\begin{array}{c}\mathrm{II} \\
\mathrm{Q}_{\mathrm{M}}^{\mathrm{O}_{2}} \\
\text { Aerobic } \\
\text { glycolysis } \\
\text { (c.mm.* } \\
\text { lactic acid } \\
\text { formed } \\
\text { in air) }\end{array}$ & $\begin{array}{c}\mathrm{III} \\
\mathrm{Q}_{\mathrm{M}}^{\mathbf{N}_{2}} \\
\text { Anaerobic } \\
\text { glycolysis } \\
\text { (c.mm.* } \\
\text { lactic acid } \\
\text { formed } \\
\text { in absence } \\
\text { of oxygen) }\end{array}$ & IV & 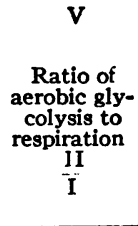 \\
\hline Bakker 1927 (15) & \multicolumn{2}{|c|}{ Exudate leukocytes of rabbits } & 0.4 & 5.7 & 6.0 & $\begin{array}{c}\text { per cent } \\
5\end{array}$ & 14.3 \\
\hline \multirow{2}{*}{$\begin{array}{l}\text { Fleischmann and Kubowitz } \\
\qquad 1927 \text { (16) }\end{array}$} & \multicolumn{2}{|c|}{ Exudate leukocytes of rabbits } & 4.5 & 14.0 & 23.3 & 40 & 3.10 \\
\hline & \multicolumn{2}{|c|}{ Blood leukocytes of geese } & 4.9 & 1.8 & 11.6 & 85 & 0.37 \\
\hline \multirow{2}{*}{ Fujita 1928 (17) } & \multicolumn{2}{|c|}{ Bone marrow cells of rats } & 9.8 & 3.7 & 21.0 & 82 & 0.38 \\
\hline & \multicolumn{2}{|c|}{ Blood leukocytes of rats } & 9.2 & 2.6 & 20.2 & 87 & 0.28 \\
\hline $\begin{array}{l}\text { Jackson, Parker, and } \\
\text { Glover } 1930 \text { (19) }\end{array}$ & \multicolumn{2}{|c|}{ Monocytes of rabbits lungs } & 5.6 & $1.4 \dagger$ & $2.7 \dagger$ & 48 & 0.25 \\
\hline $\begin{array}{l}\text { Loebel, Schorr, and } \\
\text { Richardson } 1932 \text { (23) }\end{array}$ & \multicolumn{2}{|c|}{$\begin{array}{l}\text { Monocytes of rabbits peri- } \\
\text { toneum }\end{array}$} & 2.8 & 3.0 & 4.9 & 39 & 1.07 \\
\hline \multirow{2}{*}{$\begin{array}{l}\text { Barron and Harrop } 1929 \\
\quad(18)\end{array}$} & \multicolumn{2}{|c|}{ Chronic myelogenous leukemia } & 8.0 & $9.0 \dagger$ & & & 1.12 \\
\hline & \multicolumn{2}{|c|}{ Chronic lymphatic leukemia } & 4.9 & $2.0 \dagger$ & & & 0.41 \\
\hline \multirow{5}{*}{$\begin{array}{l}\text { Glover, Daland, and } \\
\text { Schmitz } 1930(20)\end{array}$} & \multirow{2}{*}{$\begin{array}{l}\text { Myelogenous } \\
\text { leukemia }\end{array}$} & Immature & 2.4 & $\begin{array}{r}11.2 \dagger \\
2.8 \dagger\end{array}$ & $17.8 \dagger$ & 84 & 4.66 \\
\hline & & Mature & 2.6 & $\begin{array}{r}8.0 \dagger \\
17.8 \dagger\end{array}$ & $16.0 \dagger$ & 0 & 3.08 \\
\hline & \multirow{2}{*}{$\begin{array}{l}\text { Lymphatic } \\
\text { leukemia }\end{array}$} & Immature & 2.4 & $\begin{array}{r}11.2 \dagger \\
1.5 \dagger\end{array}$ & $15.9 \dagger$ & 91 & 4.66 \\
\hline & & Mature & 5.8 & $\begin{array}{l}5.2 \dagger \\
2.2 \dagger\end{array}$ & $17.2 \dagger$ & 87 & 0.90 \\
\hline & \multicolumn{2}{|c|}{$\begin{array}{l}\text { Normal human blood } \\
\text { leukocytes }\end{array}$} & 7.1 & $\begin{array}{r}8.8 \dagger \\
13.8 \dagger\end{array}$ & $13.8 \dagger$ & 0 & 1.24 \\
\hline Schlossmann 1930 (21) & \multicolumn{2}{|c|}{ Leukemic lymphocytes } & 12.0 & 0 & 21.9 & 100 & 0 \\
\hline Peschel 1930 (1) & \multicolumn{2}{|c|}{ Leukemic lymphocytes } & 5.8 & 0 & 11.1 & 100 & 0 \\
\hline $\begin{array}{l}\text { Kempner and Peschel } \\
1930(22)\end{array}$ & \multicolumn{2}{|c|}{ Human exudate leukocytes } & 22.8 & 16.8 & 57.8 & 71 & 0.74 \\
\hline \multirow{3}{*}{ Bossa (1937) (29) } & \multirow{2}{*}{$\begin{array}{c}\text { Myelogenous } \\
\text { leukemia }\end{array}$} & $\int \begin{array}{l}\text { Chronic } \\
\text { state }\end{array}$ & 10.2 & 14.9 & 29.8 & 50 & 1.46 \\
\hline & & $\begin{array}{l}\text { Acute } \\
\text { state }\end{array}$ & 12.2 & 17.8 & 23.1 & 23 & 1.46 \\
\hline & \multicolumn{2}{|c|}{ Chronic lymphatic leukemia } & 13.3 & 0.9 & 17.8 & 95 & 0.07 \\
\hline
\end{tabular}

* 1 c.mm. $=0.004$ mgm. of lactic acid.

t Lactic acid formation not determined manometrically nor chemically but assumed to be equal to sugar consumption.

to their metabolism are not tumor cells but normal young tissue cells. Secondly, the concept of a transition from normal lymphocytes to tumor cells via leukemic degenerated cells is excluded; thirdly, the aerobic glycolysis of mature lymphocytes is only a manifestation of their dying off in the blood stream or exudate. The signifi- cance of Peschel's findings has been repeatedly discussed and emphasized, for instance in great detail in W. Fleischmann's review (24, see also 25 ) and by von Bergmann (26).

Soffer and Wintrobe (27) examined oxygen and sugar consumption in the blood of patients with mye- 
logenous and lymphatic leukemia. The proportion of myeloblasts in the leukocytes specimen examined varied between 4 and 33 per cent. Soffer and Wintrobe used the same methods as Barron and Harrop (18) and came to the same conclusions : that the metabolism of the blood of myeloid leukemia resembles that of cancer, while that of lymphatic leukemia is more similar to that of normal tissue. The additional contributions of this paper are quantitative data which show that the unphysiological conditions of the method applied for examining the blood cells (absence of carbon dioxide, undefined $\mathrm{pH}$, insufficient bicarbonate and sugar concentrations) injure the cells to such an extent that, as the authors state, a considerable and persistent decrease of the rate of respiration sets in at the very beginning of their experiment, so that after the first half hour, for example, the rate of respiration has dropped to only one-third of that measured in the first ten minutes. The second result of this work, viz., that the degree of this decrease of the respiration rate depends on the number of cells per volume of suspension fluid, indicates still better the detrimental effect of the unphysiological conditions enumerated above; for it is obvious that the rate of all changes in the composition of the suspension medium (sugar-, bicarbonate concentration, $\mathrm{pH}$ ) will increase directly with the increase of the number of metabolizing cells present.

Horsters published a paper on comparative investigations on glycolysis of myeloid and lymphatic leukocytes (28). His procedure was to fill blood citrate suspensions into closed test tubes and allow them to stand for 1 to 2 hours at room temperature; then in the leukocytes layer, diluted ten times with saline solution, sugar consumption was measured in 10-minute periods and lactic acid formation in 180-minute periods. The carbon dioxide concentration was zero, the weight of the blood cells was not given. The blood was saturated with air in a standing cylinder every ten minutes, but not shaken in the intervals, so that it cannot be told for what proportion of time the cells were under aerobic and anaerobic conditions respectively. The conclusions of this paper: that suspensions of leukocytes of the myeloid type consume sugar relatively quickly in an atmosphere of air $\left(38^{\circ} \mathrm{C}\right.$.) and form equivalent amounts of lactic acid, and that sugar consumption and lactic acid formation of suspensions of lymphocytes are relatively small, are similar to the statements of Barron and Harrop (18), Glover, Daland, and Schmitz (20), and Soffer and Wintrobe (27), although Horsters omitted mentioning these authors as well as the experiments of Peschel (1) and the review of Fleischmann (24).

The most recent study of the metabolism of leukemic cells was made by Bossa (29). He obtained leukocytes by brief centrifuging and suspended them in the serum of normal people. Oxygen consumption, aerobic and anaerobic glycolysis were determined by the Warburg methods. In the total number of white blood cells the differential proportion of myeloblasts varied from 1 to 40 per cent, that of lymphoblasts from 10 to 70 per cent. Bossa arrived at the same results as previous investi- gators : in all cases of myelogenous leukemia, whether of the acute or chronic type, he found a high aerobic glycolysis $\left(Q_{\mathrm{M}}^{\mathrm{O}_{2}}: 4.2\right.$ to 37.3$)$. The average ratio of aerobic glycolysis : respiration in his cases of chronic myelogenous leukemia was exactly the same as in his cases of acute myelogenous leukemia: 1.4. In leukemic lymphocytes he found the aerobic glycolysis either very small or zero. In spite of the high aerobic glycolysis of myelogenous cells, Bossa does not consider their metabolism as signifying cancer metabolism but merely as a symptom, as Peschel had done, of cell injury within or outside the body and therefore nothing but a transitional metabolic phase before the ultimate death of the cells.

The study of leukemic lymph nodes yielded the same ambiguous result (positive aerobic glycolysis) as that of leukemic blood cells. Victor and Potter (31) and Victor and Wintersteiner (32) examined the metabolism of lymph nodes of normal mice and of mice inoculated with different lines of transmissible lymphogenous leukemia, controlling age and genetic constitution. In all cases regardless of age, line, transfer number, and host conditions, they found aerobic glycolysis, which was usually even greater in the leukemic than in the normal lymph nodes. From the presence of aerobic glycolysis in all the lymph nodes, both leukemic and normal, the authors concluded that it was impossible to differentiate infections from neoplasms using cellular metabolism as a criterion.

Table I gives a summary of the quantitative data from the above mentioned experiments on the metabolism of normal and leukemic white blood cells. It must, however, be emphasized again that only part of these results were obtained by satisfactory methods and under physiological conditions. It is evident from the table that the aerobic glycolysis-respiration ratio in granulocytes is always positive. Calculated from the given figures (Column V) it varies in mature blood and exudate leukocytes between 0.25 and 3.1 (Bakker's figure, 14.3, excluded), in leukemic granulocytes between 1.1 and 4.7; in leukemic blood lymphocytes examined under physiological conditions it is zero. That means all "normal," i.e., mature human and animal blood and exudate leukocytes, as well as the more immature granulocytes from all the patients with myelogenous leukemia, showed a lactic acid formation under aerobic conditions; the absolute values varied from 1.4 to $17.8 \mathrm{c} . \mathrm{mm}$. of lactic acid formed by $1 \mathrm{mgm}$. of leukocytes in 1 hour; whereas in the immature lewkemic lymphocytes, aerobic lactic acid formation did not occur.

\section{EXPERIMENTAL}

In a large series of experiments on 40 cases of myelogenous and 15 cases of lymphatic leukemia, I have found, in complete agreement with other authors $(1,21)$ that leukemic lymphocytes do not show any aerobic lactic acid formation, that is, that they exhibit the type of metabolism characteristic of undamaged normal young cells.

The experimental approach to the question of 
the nature of leukemic granulocytes proved to be complicated and difficult, since in most cases of myelogenous leukemia accurate measuring of the actual metabolism of the immature cells exclusively is not possible. For, if there is a large proportion of myeloblasts and the total white blood count is small, the metabolism of the myeloblasts is obscured by the respiration and splitting metabolism of the red blood cells. If, on the contrary, the white blood count is high and the proportion of myeloblasts small, the metabolism of the myeloblasts is obscured by the respiration and splitting metabolism of the mature granulocytes. The problem resolves itself into the obtaining of uninjured immature granulocytes without an admixture of mature white blood cells and of erythrocytes. The actual separation of the mature and immature white blood cells in amounts sufficient for metabolism determination is impossible. Calculation of the metabolism figures of the immature cells by merely subtracting metabolism figures of the mature cells, according to their proportion in the differential cell count, is likewise impossible because of the great variability of the metabolism figures of the mature cells, as shown in Table I. Moreover, the differential cell count is irrelevant since only the differential cell weight here is essential. The separation of red and white blood cells seems easy at first glance, but it is just this apparent ease which is the main source of error in experiments with these sensitive cells, which above all must remain uninjured in order to survive in a normal condition. Even simple procedures, such as centrifuging or sedimenting the blood by allowing it to be stationary for any length of time, or exposure to low temperatures, are sufficient to injure the cells considerably, so that it may well occur that it is not the difference in metabolism of the various types of leukocytes that is measured, but only the difference in their resistance to various injuries.

Since, therefore, a material of uninjured immature granulocytes without admixture of mature granulocytes and red blood cells obviously cannot be obtained by experimental means, investigations of the metabolism of leukemic immature cells would be impossible but for the rare opportunity of meeting with a case of leukemia in which the leukocyte count is high in comparison to the red blood cell count, and the proportion of myelo- blastic cells to mature white cells is so great that the metabolism of both red and mature white blood cells does not enter into consideration. Such cases occur with extreme rarity, and even among cases of myeloblastic leukemia cited in the literature, with a white blood cell count above 100,000 , a differential count of more than 70 to 80 per cent of myeloblasts is not often mentioned. The presence of only 20 to 30 per cent of mature white cells, however, may suffice to prevent the exact determination of the metabolism of the myeloblasts themselves. In nine years of studying the metabolism of blood cells, I have encountered only a single case presenting the conditions required. This patient had a white cell count of 180,000 with about 95 per cent of immature myeloblastic cells.

In preparing the blood specimen for the metabolism experiment, great care was taken to avoid all injury to the cells. Blood was taken from the cubital vein in heparin $(1 \mathrm{mgm}$. per $2 \mathrm{c.cm}$. of blood) and very gently shaken with glass beads in a cylinder for 3 minutes. The blood should not be taken in oxalate or citrate solution, it should not be diluted, and it should be saturated at body temperature with 5 per cent carbon dioxide in air as soon as possible. When the number of leukocytes per c.cm. of blood is very great, it may happen that within a short time after the removal of the blood from the body so much bicarbonate and sugar has been used up by aerobic glycolysis and respiration, that the aerobic glycolysis to be measured is reduced to a fraction of its optimal rate, or may even disappear. A purely oxidative metabolism may thus be simulated, which is, however, only due to low concentrations of bicarbonate or glucose, or to a more acid $\mathrm{pH}$ (33). In such instances the sugar and bicarbonate content of the blood, as well as its anaerobic glycolysis, must be determined in a preliminary experiment, and, if necessary, enough glucose and sodium bicarbonate added to make sure that during the whole time of the experiment the metabolism is measured under physiological conditions, i.e., sugar concentration 1.2 grams per liter, bicarbonate concentration 560 c.mm. per c.cm., pH 7.4.

The proportion of white and red blood cells was determined by direct hematocrit reading and checked by comparison with the total cell volume 
and number of red blood cells, assuming that a concentration of five million red. blood cells of normal size per c.mm. corresponds to a cell volume of 45 per cent. The dry weight of the total cell volume was determined according to Peschel (1).

The metabolism determinations were done manometrically. The method, frequently applied $(18,19,20,27)$, of determining aerobic lactic acid formation by measuring the sugar consumption is inadequate, since the measured decrease of the sugar concentration does not indicate how much of the sugar has been used in respiration or in the formation of glycogen (30), and how much has been actually split into lactic acid.

The blood was pipetted into three rectangular manometer vessels, each of about $18 \mathrm{cc}$. capacity, and into one conical vessel with a large insert well. The side bulbs of all four vessels contained 6 and $3 \times 0.03$ c.cm. $\mathrm{m} / 17$ lactic acid, previously weighed in. The main space of Vessel I contained $6 \mathrm{c.cm}$. of blood, that of Vessels II and III $3 \mathrm{c.cm}$. of blood, that of Vessel IV 0.2 c.cm. of $\mathrm{m} / 3$ sodium bicarbonate, and the insert well of Vessel IV 2 c.cm. of blood. The vessels were saturated, while being shaken in the thermostat at $38^{\circ} \mathrm{C}$., with gas mixtures prepared over mercury in a gasometer of 2-liter capacity: Vessels I, II, and IV with 5 per cent $\mathrm{CO}_{2} / 95$ per cent air, Vessel III with 5 per cent $\mathrm{CO}_{2} / 45$ per cent $\mathrm{CO} / 50$ per cent $\mathrm{N}_{2}$. The shaking speed employed was 180 oscillations per minute. Readings were made every five minutes without stopping the manometers. The figures remained constant for over one hour. After this time, or in other experiments after 20 minutes, the lactic acid was tipped in from the side bulbs. The retention of carbon dioxide and of lactic acid by the blood cells, as well as the metabolism figures for oxygen consumption, carbon dioxide formation, and lactic acid formation were calculated according to Warburg (34).

Table II shows the blood metabolism of the patient with myeloblastic leukemia and of a normal woman of the same age. Calculated per mgm. of dry weight of cells, the anaerobic lactic acid formation of the myeloblastic blood is 7.6 times greater, the respiration 47 times greater than that of normal blood. The absolute metabolism figures of respiration and anaerobic glycolysis are not important as compared with the finding that no lactic acid is formed by the myeloblastic blood in air, and that the aerobic glycolysis-respiration ratio, in the blood of the patient with myeloblastic leukemia, is 0 to 235 against 45 to 5 in normal blood.

From a comparison of the metabolism figures of myeloblastic blood to those of normal blood one can obtain the metabolism figures of the myeloblasts themselves, as shown in Table III.

The absolute value of the rate of respiration is of the same magnitude as that of immature leukemic lymphocytes and of human erythroblasts, 154 times greater than that of mature erythrocytes, but only one-third of that of human exudate leukocytes. The respiratory quotient of myeloblasts in air is 0.75 . The rate of anaerobic glycolysis of leukemic granulocytes and leukemic lymphocytes is nearly the same: 11.5 and 11.1 c.mm. of lactic acid is formed in one hour by 1 mgm. (dry weight) of cells, against $58 \mathrm{c.mm}$. formed by human exudate leukocytes, $51 \mathrm{c} . \mathrm{mm}$. formed by human nucleated red blood cells, and 0.5 c.mm. formed by mature erythrocytes (Table IV). An amount of lactic acid equal to the cell

TABLE II

Metabolism of myeloblastic and of normal blood (calculated per 100 mgm. of total blood cell dry weight and per 1 hour)

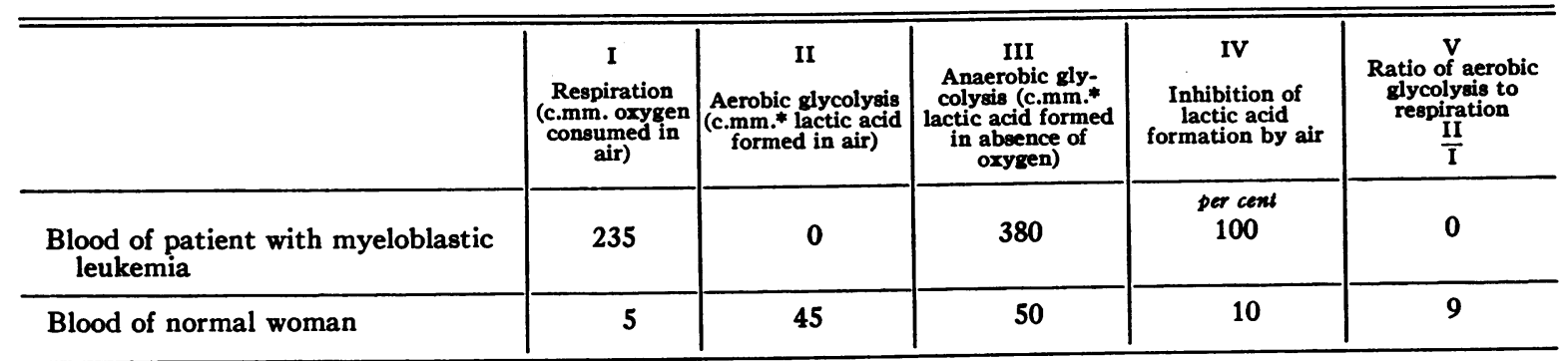

* 1 c.mm. = 0.004 mgm. of lactic acid. 
TABLE III

Calculation of metabolism figures for $1 \mathrm{mgm}$. (dry weight) of myeloblasts

\begin{tabular}{|c|c|c|c|c|c|}
\hline $\begin{array}{l}100 \text { mgm. of blood cells of patient with myeloblastic } \\
\text { leukemia ( } 30 \text { per cent white blood cells, } 70 \text { per cent } \\
\text { red blood cells) }\end{array}$ & 235.0 & 0 & 380 & $\begin{array}{c}\text { per cent } \\
100\end{array}$ & 0 \\
\hline $\begin{array}{l}70 \text { mgm. of blood cells of normal person ( } 70 \text { per cent } \\
\text { of the cells of the myeloblastic blood) }\end{array}$ & 3.5 & 31.5 & 35 & 10 & 9 \\
\hline $\begin{array}{l}30 \text { mgm. of myeloblasts ( } 30 \text { per cent of the cells of } \\
\text { myeloblastic blood) }\end{array}$ & 231.5 & 0 & 345 & 100 & 0 \\
\hline $1 \mathrm{mgm}$. of myeloblasts & 7.7 & 0 & 11.5 & 100 & 0 \\
\hline
\end{tabular}

$* 1$ c.mm. $=0.004$ mgm. of lactic acid.

TABLE IV

Metabolism of human blood cells (calculated per $1 \mathrm{mgm}$. of dry weight of cells per hour)

\begin{tabular}{|c|c|c|c|c|c|}
\hline Erythroblasts (35) & 12.80 & 24.30 & 50.6 & $\begin{array}{c}\text { per cent } \\
52\end{array}$ & 1.92 \\
\hline Exudate leukocytes $(22,35)$ & 22.80 & 16.80 & 57.8 & 71 & 0.74 \\
\hline Leukemic lymphocytes (1) & 5.80 & 0 & 11.1 & 100 & 0 \\
\hline Myeloblasts & 7.70 & 0 & 11.5 & 100 & 0 \\
\hline
\end{tabular}

dry weight is formed under anaerobic conditions by myeloblasts in 22 hours, by erythroblasts in 5 hours, by erythrocytes in 500 hours, by exudate leukocytes in a little over 4 hours. Under aerobic conditions the same amount of lactic acid is formed by erythroblasts in 10 hours, by exudate leukocytes in 15 hours, by erythrocytes in 550 hours. Lymphoblasts and myeloblasts form no lactic acid aerobically.

The metabolic features of the maturity process of red blood cells are well seen in the metabolism figures of human erythroblasts and erythocytes (35). The rate of respiration, as well as that of lactic acid fermentation is considerably lower in the older than in the younger cells. But since the rate of respiration has decreased much more than the rate of fermentation (250 times against 50 times) a disturbance of the aerobic glycolysisrespiration ratio results. This ratio in mature erythrocytes is 9, in erythroblasts 2. Table V contrasts the white blood cell metabolism in the case of pure myeloblastosis with that in cases of myelogenous leukemia with a smaller proportion of immature cells. In Case I the proportion of the more mature cells (segmented, juvenile and myelocytic granulocytes, and lymphocytes) to the myeloblasts is $98: 2$, in Case II 50:50, in Case III 5:95. The aerobic glycolysis-respiration ratio is, in Case I 7.2, in Case II 1, in Case III 0.

As demonstrated for red blood cells, in white blood cells also the increase of the aerobic glycolysis-respiration ratio is evidence only of the increasing age or the maturity of the cells. The figures of Table V, especially of Column V, show 
TABLE v

Blood metabolism of three cases of myelogenous leukemia with different proportions of myeloblasts to more mature granulocytes

\begin{tabular}{|c|c|c|c|c|c|c|c|c|c|c|c|}
\hline & $\begin{array}{c}\text { Total white } \\
\text { blood cell } \\
\text { number } \\
\text { per c.mm. }\end{array}$ & $\begin{array}{l}\text { Lympho- } \\
\text { cytes }\end{array}$ & $\begin{array}{c}\text { Seg- } \\
\text { mented, } \\
\text { stab and } \\
\text { juvenile } \\
\text { forms }\end{array}$ & $\begin{array}{c}\text { Myelo- } \\
\text { cytes }\end{array}$ & $\begin{array}{c}\text { Myelo- } \\
\text { blasts }\end{array}$ & $\begin{array}{c}\text { Proportion of } \\
\text { more mature } \\
\text { granulocytes } \\
\text { to myeloblasts }\end{array}$ & $\begin{array}{c}\mathrm{I} \\
\mathrm{Q}_{\mathrm{O}_{2}}^{\cdot} \\
\text { Respiration }\end{array}$ & $\begin{array}{c}\text { II } \\
\mathrm{Q}_{\mathrm{M}}^{\mathrm{O}_{2}} \\
\begin{array}{c}\text { Aerobic } \\
\text { glycolysis }\end{array}\end{array}$ & $\begin{array}{c}\text { III } \\
\mathrm{Q}_{\mathrm{M}}^{\mathrm{CO}} \\
\text { Anaerobic } \\
\text { glycolysis }\end{array}$ & 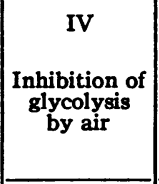 & $\begin{array}{c}\mathrm{V} \\
\text { Ratio of } \\
\text { aerobic ogly- } \\
\text { colysis to } \\
\text { respiration } \\
\frac{\text { II }}{\mathrm{I}}\end{array}$ \\
\hline I & 186,000 & 2 & 67 & 29 & 2 & $98: 2$ & 2.8 & 20.2 & 24.6 & $\begin{array}{c}\text { per cent } \\
18\end{array}$ & 7.2 \\
\hline II & 52,000 & 3 & 18 & 29 & 50 & $50: 50$ & 2.4 & 2.4 & 5.3 & 55 & 1.0 \\
\hline III & 179,000 & 2 & 1 & 2 & 95 & $5: 95$ & 7.7 & 0 & 11.5 & 100 & 0 \\
\hline
\end{tabular}

quantitatively why former investigators $(18,20$, 27) ascribed the properties of cancer-cell metabolism to leukemic myelogenous cells. All the instances of myelogenous leukemia appearing in the literature, where metabolism determinations were made, belong to the same group as Cases I and II of our Table V, i.e., the leukocytes examined were not young immature leukemic granulocytes but mixtures of "old " mature and "young" immature cells in which these old and dying cells predominated to so great an extent that the characteristic metabolism of the myeloblasts as such was entirely obscured.

The question, therefore, of the nature of the leukemic myeloblastic cell is definitely answered, it seems to me, by the results on the energy supplying reactions of the myeloblastic cells. The metabolism of myeloblasts is purely oxidative, there is no aerobic splitting of sugar into lactic acid which is invariably found in benign and, to a greater degree, in malignant tumor cells, in injured cells, mature leukocytes, and erythrocytes. Even the aerobic glycolysis of the erythrocytes, which constitute 70 per cent of the cell volume of the blood examined is, in the manometrical experiment, completely overshadowed by the high myeloblastic respiration. Myeloblasts, contrary to the mature blood and exudate leukocytes of healthy and leukemic people, possess the characteristic metabolism of uninjured normal young cells. From the standpoint of cellular physiology one may say definitely that the metabolism of myeloblasts differs fundamentally from that of malignant tumor cells.

In previous experiments (22) we examined the chemical composition of tissue fluids in normal and inflamed areas and found a disturbed equili- brium of oxygen, carbon dioxide, sugar, lactate, and bicarbonate as a result of inflammation. The products of the metabolism of exudate leukocytes which accumulated in the closed manometer vessel, also accumulated in very high amounts in the inflamed area, and were not carried off by the blood or lymph flow. After an inflammation period of three days, the sugar concentration of sterile blisters of the skin, for instance, was zero against $100 \mathrm{mgm}$. per cent in normal tissue fluid; the sodium lactate concentration was above 125 mgm. per cent against $10 \mathrm{mgm}$. per cent; the bicarbonate had decreased to half its amount and the $\mathrm{pH}$ had dropped to values as low as 6.2. We stated then, as our opinion, that these chemical changes, due for the most part to the aerobic glycolysis of the leukocytes, play an important rôle in the fight of the body against bacteria, since under these unfavorable conditions of the nutrient medium bacteria are severely damaged, or even starved to death. This opinion was supported by von Bergmann (26) and Lohmann $(33,36)$.

Since, in contrast to the mature white blood cells, the myeloblastic cells lack completely aerobic glyoclysis, they are unable to produce any of the above mentioned chemical effects. The function of the mature leukocytes, therefore, can not be taken over by the more immature leukemic cells, and it is obvious why an increase of immature leukocytes with a decrease of mature forms leads to serious danger whenever pathogenic bacteria attack the body. The detrimental factor is not the presence of myeloblasts, or lymphoblasts, but the absence of mature white cells capable of forming lactic acid under aerobic conditions.

For the vague concept of "weakened resistance" of patients with myeloblastic or lymphoblastic 
leukemia toward bacterial infection, we may substitute a definite quantitatively measurable chemical fact, namely, that the purely oxidative metabolism and total lack of aerobic glycolysis of the myeloblasts and lymphoblasts renders them unable to carry out the bactericidal "reactions of inflammation."

\section{CONCLUSIONS}

1. Whether leukemic cells are malignant or benign tumor cells, or normal young tissue cells, can not be decided by morphological investigation. The question can be answered definitely by studies of the metabolic reactions of leukemic blood cells.

2. The metabolism of the blood cells from 15 patients with lymphatic leukemia and from 40 patients with myelogenous leukemia was determined manometrically with the Warburg method. Myeloblasts as well as lymphoblasts-in contrast to the more mature forms of leukocytes-have a purely oxidative metabolism and do not form lactic acid under aerobic conditions. The aerobic glycolysis-respiration ratio in the blood of a patient with myeloblastic leukemia $(180,000$ white cells per c.mm., 95 per cent myeloblasts) was 0 to 235 , against 45 to 5 in normal blood. The anaerobic glycolysis of the myeloblastic blood was 7.6 times, the respiration 47 times greater than that of normal blood. The respiratory quotient of myeloblasts, measured in air, was 0.75 . Aerobic glycolysis which occurs (independent of the rate of respiration) in more mature leukocytes was found to be a symptom of their ageing and dying off. Myeloblasts as well as lymphoblasts exhibit the characteristic metabolism of uninjured normal young cells, and not that of cancer cells.

3. The weakened resistance of patients with myeloblastic or lymphoblastic leukemia toward bacterial infection is explained by the absence of aerobic glycolysis in immature leukemic blood cells.

\section{BIBLIOGRAPHY}

1. Peschel, E., Stoff wechsel leukaemischer Lymphocyten. Klin. Wchnschr., 1930, 2, 1061.

2. Virchow, R., Die krankhaften Geschwuelste. Bd. II, Hirschwald, Berlin, 1864, p. 568.

3. Banti, G., Die Leukaemien. Centralbl. f. allg. Path. u. path. Anat., 1904, 15, 1.

4. Ribbert, H., Menschliche Zellen als Parasiten. Deutsche med. Wchnschr., 1907, 33, 329.
5. MacCallum, W. G., A Textbook of Pathology. W. B. Saunders Co., Philadelphia, 1936, 6th ed., p. 875.

6. Boyd, W., The Pathology of Internal Diseases. Lea and Febiger, Philadelphia, 1935, 2d ed., p. 618.

7. Ewing, J., Neoplastic Diseases. W. B. Saunders Co., Philadelphia, 1928, 3d ed., p. 397.

8. Richter, M. N., and MacDowell, E. C., Experiments with mammalian leukemia. Physiol. Rev., 1935, 15, 509.

9. Sternberg, C., Blutkrankheiten, Leukaemien. In : Henke-Lubarsch, Handb. d. spez. Path. Anat. u. Hist., 1926, 1, 56.

10. Naegeli, O., Blutkrankheiten und Blutdiagnostik. Springer, Berlin, 1931, 5th ed.

11. Warburg, O., Stoff wechsel der Tumoren. Springer, Berlin, 1926.

12. Grafe, E., Die Steigerung des Stoff wechsels bei chronischer Leukaemie und ihre Ursachen. Deutsches Arch. f. klin. Med., 1911, 102, 406.

13. Levene, P. A., and Meyer, G. M., On the action of leukocytes on glucose. J. Biol. Chem., 1912, 12, 265.

14. Bürger, M., Untersuchungen über Hämoglykolyse. Ztschr. f. d. ges. exper. Med., 1923, 31, 1.

15. Bakker, A., Einige Uebereinstimmungen im Stoffwechsel der Carcinomzellen und Exsudatleukocyten. Klin. Wchnschr., 1927, 6, 252.

16. Fleischmann, W., and Kubowitz, F., Ueber den Stoffwechsel der Leukocyten. Biochem. Ztschr., 1927, $181,395$.

17. Fujita, A., Ueber den Stoff wechsel der Koerperzellen. Biochem. Ztschr., 1928, 197, 175.

18. Barron, E. S. G., and Harrop, G. A., Jr., Studies on blood cell metabolism. Metabolism of leukocytes. J. Biol. Chem., 1929, 84, 89.

19. Jackson, H., Parker, F., and Glover, E. C., Studies of diseases of the lymphoid and myeloid tissues. I. J. Exper. Med., 1930, 52, 547.

20. Glover, E. C., Daland, G. A., and Schmitz, H. L., The metabolism of normal and leukemic leukocytes. Arch. Int. Med., 1930, 46, 46.

21. Schlossmann, H., Ueber den Stoff wechsel von Lymphocyten. Biochem. Ztschr., 1930, 219, 463.

22. Kempner, W., and Peschel, E., Stoff wechsel der Entzuendung. Ztschr. f. klin. Med., 1930, 114, 439.

23. Loebel, R. O., Shorr, E., and Richardson, H. B., The influence of adverse conditions upon the respiratory metabolism and growth of human tubercle bacilli. J. Bact., 1933, 26, 167.

24. Fleischmann, W., Pathologische Physiologie des Stoffwechsels weisser Blutzellen. Wien. med. Wchnschr., 1933, 83, 215.

25. Fleischmann, W., Der Stoff wechsel des geschaedigten Gewebes. Naturwissenschaften, 1936, 24, 15.

26. von Bergmann, G., Funktionelle Pathologie. Springer, Berlin, 1932, p. 170.

27. Soffer, L. J., and Wintrobe, M. M., The metabolism of leukocytes from normal and leukemic blood. J. Clin. Invest., 1932, 11, 661. 
28. Horsters, H., Vergleichende Versuche ueber die Glykolyse durch myeloische und lymphatische Leukocytenformen des menschlichen Blutes. Ztschr. f. d. ges. exper. Med., 1936, 97, 479.

29. Bossa, G., Sul metabolisma dei leucociti leucemici. Haematologica, 1937, 18, 673.

30. Willstätter, R., and Rohdewald, M., Ueber Aufbau und Abbau des Glykogens durch Leukocyten. (Zehnte Abhandlung ueber Enzyme der Leukocyten.) Ztschr. f. physiol. Chem., 1937, 247, 115.

31. Victor, J., and Potter, J. S., Studies in mouse leukemia. XI. Metabolic effects of host constitution. J. Exper. Med., 1934, 60, 547.

Studies in mouse leukemia : Pre-leukemic changes in lymphoid metabolism. Brit. J. Exper. Path., 1935, 16, 234.

Studies in mouse leukemia: Metabolic observations in spontaneous lymphatic leukemia. Brit. J. Exper. Path., 1935, 16, 253.

32. Victor, J., and Wintersteiner, M. B., Studies in mouse leukemia. X. Metabolic differences between transmission lines of mouse lymphatic leukemia. Am. J. Cancer, 1934, 22, 561.

33. Lohmann, R., Zellstoff wechsel und Entzuendung. Klin. Wchnschr., 1938, 17, 427.

Biologie der Entzuendung. Ztschr. f. klin. Med., 1938, 135, 316.

34. Warburg, O., Kubowitz, F., and Christian, W., Ueber die Wirkungen von Phenylhydrazin und Phenylhydroxylamin auf den Stoff wechsel von roten Blutzellen. Biochem. Ztschr., 1931, 242, 170.

35. Kempner, W., Metabolism of human erythroblasts. J. Clin. Invest., 1936, 15, 679.

36. Lohmann, R., Krebsstoff wechsel und Entzuendung. Klin. Wchnschr., 1931, 10, 1799.

Manometrische Untersuchungen ueber Stoffwechsel und Wachstum von Bakterien unter dem Einfluss von ultraviolettem Licht und unter den Bedingungen der Entzuendung. Klin. Wchnschr., 1934, 13, 1112. 